\title{
Applying the Rhetoric of Renewal Model in a Contemporary African Context: Lessons Learned from the Royal Dutch Shell Oil Crisis in Nigeria
}

\author{
Vincent D. Manzie () \\ Department of Applied Communication Studies, University of Arkansas at Little \\ Rock, Little Rock, Arkansas, USA
}

\begin{abstract}
This article applies the crisis renewal model to a multinational organizational crisis in Nigeria not only to analyze the crisis points of conflict in the multinational's corporate rhetoric but also to examine how global relations; situated exigencies; and cultural, social, and economic tensions contextualize corporate communication strategies during crises. Rhetoric of renewal was evident as the multinational corporation responded to a prolonged crisis involving multiple state and local stakeholders. Although the renewal model itself redresses traditional Aristotelian crisis rhetoric models, the Nigerian situation calls for a significant reframing of rhetorical strategies accountable to the colonialist legacies, cultural traditions, political volatilities, and socioeconomic particularities of these contexts. Lessons learned and implications for organizational crisis rhetoric and practices in an age of increasing global interconnectedness are offered.
\end{abstract}

KEYWORDS: Renewal; corporate rhetoric; cultural exigence; crisis response; multinational

Dutch Shell, a multinational energy and petrochemical corporation, established an oil venture in Nigeria's Niger Delta in 1936. It soon ran into oppositional struggles with the locals in the oil-rich region following heavy and frequent oil spills and gas flaring in the communities (McGreal, 1993). Local communities have protested against the multinational's operations in the region, disputing ownership of oil and land and accusing Shell of environmental degradation, including heavy pollution, poisoning of fishing grounds, and destruction of farmlands by frequent oil spills and gas flaring. In addition, accusations

CONTACT Vincent D. Manzie • E-mail: vdmanzie@mtu.edu • University of Arkansas at Little Rock, 6 Sanibel Cove, Little Rock, AK 72210, USA 
of exploitation, human rights abuse, corruption, and killings continue to haunt Shell in the Niger Delta (Steele, 1995; see also Amaize, 2011; Iwori, 2014; James, 2015). The company has responded to these issues with crisis renewal communication strategies that appear to shift toward a responsive revision of relationships with local stakeholders. Yet my analysis calls into question the adequacy of current crisis communication models to address how situated exigencies and cultural, social, and economic tensions contextualize corporate communication strategies during multinational crises.

Between the early 1990 os and mid-2000s, Royal Dutch Shell's response to the Niger Delta crisis very much contrasted with the approach it took from 2006 to 2016. Shell refers to its response to the crisis in the 1990 s to mid-20oos as an "old" or "previous" approach; its "new approach" to crisis response was effectively implemented starting in 2006 (see Shell Nigeria, 2012). The old approach, according to data analyzed in this study, was predominantly a rhetoric of denial. The new approach conforms to the discourse of renewal. This article focuses on this new approach.

I apply the discourse of renewal model (cf. Seeger \& Ulmer, 2001, 2002; Seeger, Ulmer, Novak, \& Sellnow, 2005; Sellnow \& Seeger, 2013; Ulmer, Seeger, \& Sellnow, 2007) to assess the model's application in a contemporary African context. The Nigerian case stands out as a compelling example of the model's application outside Europe and North America. I begin with a brief overview of three crisis communication models (including the renewal model) widely applied in the field. This is followed by a detailed analysis of the discourse of renewal model as applied by Royal Dutch Shell in its response to the crisis in the Niger Delta region. I conclude with lessons learned about corporate communication, crisis, and renewal in an African context.

\section{Models in Crisis Communication}

Corporate crisis communication has developed through case descriptions of the communication strategies used by corporate leaders and spokespeople in reaction to image threats. Based on post hoc rhetorical analyses, crisis scholars have categorized these strategies. The first 
schemas drew on classical Aristotelian conceptions of apologia, a speaker-centered approach that mitigates the threat to corporate image through various strategies of apology or denial (Benoit, 1997; Ware \& Linkugel, 1973). A later schema is informed by psychological theories of attribution to offer schemas based in stakeholder perceptions of responsibility and blame (see Coombs, 2007). Yet the emphasis on corporate leaders, defensive strategies, and the goal of protecting or reinstating corporate image remained. More recently, a proactive and positive approach to corporate crisis communication has been advanced that shifts from post hoc analyses and defensive strategies to ethical communicative relationships: the renewal model of crisis communication (see Ulmer et al., 2007; Ulmer, Sellnow, \& Seeger, 2011).

Introduced by Ulmer, Seeger, and Sellnow in 2007, the discourse of renewal shifts from reactive image repair and reputation management accounts to a proactive relational perspective (Seeger \& Ulmer, 2001, 2002; Seeger et al., 2005; Ulmer et al., 2007). Early formulations of the discourse of renewal (Seeger \& Ulmer, 2001, 2002) raised concerns about the absence of a critical perspective in crisis rhetoric. They argued for ethical, optimistic, provisional, and prospective communication, evidenced in their study of the "virtuous responses" offered by CEO Aaron Feuerstein of Malden Mills and Milt Cole, owner of Cole Hardwoods, during the fire disasters that razed their firms. Seeger et al. (2005) further invoked the notion of "change" that accompanies crises, grounding their argument in a study of a "postcrisis discourse of renewal" in the response of executives in the firm Cantor Fitzgerald after the September 11, 2001, World Trade Center attacks in which the firm is reported to have lost 658 of its 960 employees. As is evident in these case studies, renewal carries implications for leadership, ethics, and rhetorical response.

Ulmer et al. (2007) noted the following key characteristics that provide a discourse of renewal framework for analyzing crisis communication: (a) advancing provisional as opposed to strategic responses, (b) adopting a prospective rather than retrospective vision, (c) capitalizing on the opportunities embedded in the crisis, and (d) supporting an ethical leader as the face of the company advocating for corrective action and change. Among the conditions conducive for such a renewal 
discourse are crises based on natural causes, the "entrepreneurial spirit and greater autonomy" exercised by private owners over public companies, a willingness to correct mistakes and instigate change, and prior positive stakeholder relationships that can support renewal (Ulmer et al., 2007; see also Reierson \& Littlefield, 2012).

Ulmer et al. (2011) elaborated four theoretical dimensions of the discourse of renewal: (a) organizational learning, (b) ethical communication, (c) prospective rather than retrospective vision, and (d) effective organizational rhetoric. Notably, a prospective vision includes optimism and emphasizes the need to focus on future opportunities. Effective organizational rhetoric has to do with organizational leaders constructing or "structuring a particular reality for organizational stakeholders and publics" (Ulmer et al., 2011, p. 219). The goal is to make use of opportunities inherent in crises such that organizations are able to renew themselves and their stakeholder relationships. I draw on the elements of the renewal model in analyzing the Niger Delta crisis.

\section{Data and Procedures}

Cases are widely applied in crisis communication research. The current renewal model developed through case analyses (Seeger \& Ulmer, 2001, 2002; Seeger et al., 2005; Ulmer, 2001; Ulmer \& Sellnow, 2002). The method of case analysis that examines contemporary complex phenomenon in real-world contexts makes case analysis a suitable research method (Yin, 2009). The case development in crisis communication is descriptive, and the analysis proceeds deductively by fitting the rhetorical model to the description of the case. However, these models were originally developed inductively by examining cases of corporate crises to identify rhetorical strategies. For example, the image repair model has been expanded by examining particular cases for additional elements of classical apologia. Similarly, the discourse of renewal model was developed by identifying affirmative responsive strategies in particular exemplars of corporate crisis response.

Accordingly, the present study applied the four theoretical dimensions that inform the discourse of renewal model as the frames of analysis (Ulmer et al., 2007; Ulmer, Sellnow, \& Seeger, 2011). Data 
for the study were collected from 351 newspaper articles, company documents, and local and international nongovernmental organization (NGO) reports spanning the period 1990-2016. Data sources included newspaper reports and radio texts, company documents (e.g., environmental impact assessment reports, mission and value statements, ethical code of conduct statements, and press releases on company websites), NGO reports, and reports by other independent organizations (e.g., Center for Investigative Journalists). The newspaper reports and radio texts were downloaded from LexisNexis Academic database. The reports came from local Nigerian and international newspapers and wire services. The radio texts were specifically from the BBC World Service. Other Web databases and archives owned by Nigerian and international NGOs also served as sources for data. These sources documented information about the crisis and the communities affected and came from both company leaders and spokespersons as well as villagers and leaders from local communities. The unit of analysis was specific statements made during and about the crisis drawn from these data sources.

Data analysis proceeded through three stages. First, direct quotations (statements) by organizational leaders, spokespersons, and members of local communities were identified and inductively categorized according to their characterizations of the conflict. The quotations were assembled by reading through the newspaper reports, radio texts, company documents, NGO reports, and studies conducted by independent organizations. A separate file was created for these direct quotations. The direct quotations provided a rich description and sense of the oppositional struggles and points of conflict in the crisis from the point of view of the organization and from the perspective of affected communities. The second stage involved matching these direct quotations to the discourse of renewal to determine which of the four theoretical dimensions of the renewal model were evoked by organizational leaders and spokespersons. This technique is one of three data analysis procedures, that is, pattern matching identified by Yin (2009). The third stage critically analyzed the omissions, discrepancies, and divergences between the discourse of renewal model and the rhetoric of the Shell crisis that emerged following the pattern matching in Stage 2 of the 
data analysis. At this stage, it was possible to see how the major points of conflict in the crisis emerged.

\section{The Crisis in Nigeria}

Protests against Shell have been mounting since 1990, as local communities hold the company responsible for the plight of the people (see McGreal, 1993). These protests have often stalled the company's operations in the region. I will briefly describe three issues enflaming tensions in the region: a history of local anger and violent protest, the environmental degradation caused by oil spills, and the daily oppression of gas flaring.

The history of anger and protest among local communities against Shell is illuminated by the story of protests by the people of Ogoni, a local community in the Niger Delta (McGreal, 1993; Steele, 1995). The leader of the Movement for the Survival of the Ogoni People (MOSOP), Ken Saro-Wiwa, led vigorous protests that attracted national and international attention, first against Shell, then against the then military regime over the neglect of the oil-rich region. Together with eight other Ogoni people, Saro-Wiwa was sentenced to death by hanging on November 10, 1995, by the military regime (Steele, 1995). This provoked anger and condemnation against Shell by both the people of Niger Delta and international human rights and environmental activists, as they accused Shell of supporting the executions. Jonathan Steele (1995), a reporter with the Guardian (United Kingdom), offered a poignant description of the perception that Ken Saro-Wiwa was paying the price for daring to

take action against the rape of their land, which left their soil and water polluted and gave them nothing except a legacy of rusting pipelines, thousands of unsightly wells and refineries, and no material benefits from the oil profits at all. (p. 3)

In subsequent years, the MOSOP vowed to continue protesting any resumption of oil production in Ogoniland (Amaize, 2011). Over 20 years since Saro-Wiwa's death, the Ogoni communities have continued to accuse Shell and hold the company responsible for environmental 
degradation (e.g., oil spills, gas flaring). In 2013, a resident quoted in a newspaper report stated that "for owning" oil resources, the people of the Niger Delta "have been paid with tears and blood" (Nzeshi, 2013, para. 8), adding that "lands have been contaminated, water polluted, economic life destroyed, environment abused and the people brutalized" (Nzeshi, 2013, para. 8). The Ogoni communities are just one among many local communities in which ongoing protests have disrupted Shell's operations and attacked pipelines operated by the company, continuing through the present day.

Environmental degradation caused by oil spills is a contentious issue in the crisis. According to company documents, oil spills occur year-round. For example, between 2011 and 2016, there have been spills every month. The monthly average for spills was a little more than 11 spills per month in 2014 ("Shell Oil Spill Data," n.d.). McGreal (1993), in a newspaper report, painted the picture of oil spills in the Niger Delta, quoting a resident of one of the communities in the region who is said to have watched for weeks as a "fine spray of petroleum coated the bamboo and palm trees around the Sasiga rivulet until, mixed with acid rain and humid air, it gave the plants the milky brown sheen of a chocolate forest" (p. A8; see also Amanze, 2012). The news report indicated that this was the result of a burst pipe from one of Shell's pumping stations.

Finally, the practice of gas flaring creates oppressive conditions for local residents. In January 2012, oil companies in Nigeria flared 30 billion standard cubic feet of gas (Cook, 2012). In one of the communities in the Niger Delta, a fisherman narrated the ordeal of gas flaring: "Because of the flares it is so hot, it is smoky, the air is thick and it is constantly daytime here" (Mark, 2012, p. 7). The fisherman further stated, "Our rivers are black and the [acid] rain eats our houses. Our bodies are covered in oil. You feel that if you live to old age here, it is a miracle" (p. 7).

In recent years, Shell has had to face several lawsuits over its operations in the Niger Delta. In January 2015, the company agreed to a settlement in a case in the United Kingdom by paying $£ 55$ million as compensation to the Niger Delta community of Bodo for oil spills and other environmental damage (Alike, 2015). Supported by NGOs like 
Amnesty International, local communities have brought suit against Shell in international courts in an attempt "to hold Shell to account" (Alike, 2015, para. 2) for its operations in the Niger Delta region. In 2018, the British High Court ruled that the two communities could not pursue legal settlement for Shell's abuses in British courts, "a setback to attempts to hold British multinationals liable at home for their subsidiaries' actions abroad" (George \& Owolabi, 2018, para. 2). Clearly there are ongoing tensions and anger fueling the opposition among local communities to Shell's practices and presence. These immediate tensions are complicated by a complex exigence embedded in the crisis.

\section{A Complex Exigence}

The prolonged crisis which Shell faces in the Niger Delta region is complicated by several exigencies embedded within the region's history, cultural, social, and economic relations. These exigencies are briefly explained in the following paragraphs.

Protesting communities describe their ownership over land as "ancestral" (Iwori, 2014, para. 5). Ancestral claims over ownership of land are creating a complex situation in which host governments lease out lands to multinational corporations and these corporations are confronted by oppositional struggles from local communities who not only see the land as their inheritance but also consider the resources on these lands (such as forest products and crude oil) as belonging to the communities. Their claims are grounded in precolonial relations and the bureaucratic impenetrability, corruption, and exploitation of colonial and postcolonial land regulations. ${ }^{1}$

The inequitable distribution of wealth from oil resources is well documented; both self-assessed poverty and low standards of living and education are critical factors in local dissatisfaction with both government and multinational management of oil resources. Not only have the dominant occupations in the area, such as fishing and farming, been undermined but the distribution of resources between the federal, state, and local governments has not trickled down to local communities (see Niger Delta Development Commission, 2005).

Along with economic issues, a critical social factor complicating 
relations between multinationals and local communities is the presentness of tradition and history in everyday life. Alagoa (2004) has argued that in the Niger Delta, "the past is so manifestly a part of the present among communities of the region" (p. 63). In fact, Alagoa argued that conflicts occur in the region when "history" is not considered by parties involved. He pointed out that

policymaking ... has proved ineffective to contain the enormous problems of the Niger Delta region ... in part, the result of disagreements over historical interpretation within communities, and the lack of a historical perspective or neglect of the historical factor by government and oil corporations. (p. 64)

Any present actions or conduct are contextualized within communities' history.

I have identified situated exigencies that trouble the relations between Shell and local stakeholders: claims over land and crude oil by local communities complicated by colonial and postcolonial reforms and social and economic relations enshrined in the modes of organizing contextualized within communities' history. The next section discusses Shell's communication response to the crisis.

\section{Royal Dutch Shell Crisis Response}

The multinational's rhetoric of renewal emerged in 2006 when the company brought forth a Global Memorandum of Understanding (GMoU). The GMoU is a written statement of understanding between Shell and clusters of communities that details roles of all parties in the implementation of community development projects as the company sought to improve its community relations. Shell has referred to this document as a "new way of working with communities" (Shell Nigeria, 2012, para. 1).

According to Shell, "the GMoU represents an important shift in approach, placing emphasis on more transparent and accountable processes, regular communication with the grassroots, sustainability and conflict prevention" (Shell Nigeria, 2012, para. 5). Shell has explained 
this new approach as being bottom-up. The GMoU represents Shell and the state and local governments in Nigeria as actors who simply facilitate the implementation of decisions made by communities. In concrete terms, Shell described its role in the GMoU as a funding and capacity-building body. Shell explained that communities "take key decisions" and "drive" their own development as they elect representatives to community development boards; these boards decide on community development (Shell Nigeria, 2012, para. 2). Shell contended that this approach has been successful, pointing to these aspects: (a) more representative and transparent management; (b) improved cohesion and cooperation; (c) increased local ownership and accountability; (d) increased participation, including from women; (e) improved innovation and learning; and (f) creation of a platform for other development actors (Shell Nigeria, 2012, para. 3). The GMoU has realized a discourse of renewal in that it has restructured relationships among key stakeholders and positioned Shell as a benefactor and facilitator of communal and inclusive local decision-making groups.

Along with this revision of Shell's community relationships, related elements of the discourse of renewal were evident in the multinational's communication response. The ethical element emerged as the company's leaders repeatedly pointed to virtues of accountability, transparency, and responsibility in their communication. Company officials touted the new approach to managing the crisis as a strategy that "seeks to increase transparency and accountability around project delivery and give communities greater ownership of projects from their inception" (Nwachuku, 2015, para. 14). Following an oil spill in a local community called Bonga, the country managing director of Shell positioned the company as a responsible organization when he stated, "As a prudent corporate citizen, [Shell] will tackle all the oil its teams can see offshore or which has come onshore in this area, including oil spilled by third parties" ("Shell First Oil Produced," 2011, para. 3). In another statement, the country managing director praised the company for being socially responsible, declaring that "this is one of the biggest corporate social responsibility portfolios operated by a private company in Sub-Saharan Africa, and it shows that we care for the wellbeing of the communities in which we do business" (Alike, 2011, para. 5). Furthermore, the 
company, through its leaders and spokespersons, frequently communicated "commitments" to working with communities (Oyadongha, 2011, para.5) and would frequently portray the company as an organization that fulfills promises and respects and implements agreements reached with clusters of communities and international bodies: "[Shell] has always been committed to contributing its share of the environmental restoration fund," a company official said in a statement (Alike, 2015, para. 6o; see Chinwo, 2013; Onukwugha, 2011).

The ethical component of the discourse of renewal was also evident when company leaders touted the importance of the company's "quality community leadership" (Chinwo, 2013, para. 6) and also that the company "believed in value-driven partnership" with communities (Oyadongha, 2011, para. 10).

Shell's communication response also evoked the element of learning. The country managing director of Shell in Nigeria is quoted in a 2011 newspaper report as he justifies the new approach to management in the Niger Delta region, asserting that Shell has "improved upon how it engaged its host communities to deliver projects and programs," adding that the company "introduced the Global Memorandum of Understanding in 2006 as a novel way of working with communities" (Onukwugha, 2011, para. 4). This statement strongly suggests the element of organizational learning and willingness to implement lessons learned for positive change. Earlier in 2010, another company official evoked the fact that Shell has learned from the previous failed management approach, saying, "The overall purpose [of the GMoU] was to eliminate the inherent weakness in previous social performance strategies and to involve communities in project identification, implementation and management" (Onah, 2010, para. 7). In a meeting in 2012 with then Nigerian president Goodluck Jonathan, following accusations from the president against Shell for not doing enough to clean up oil spills and prevent further spills, Shell's outgoing Managing Director Brindel evoked lessons learned by the company. He pointed out that "they [Shell] have come a long way which led to the fashioning of the Global Memorandum of Understanding" and that the company was already addressing the issues (Ogbu, 2012, para. 21). Statements from company officials also frequently pointed to how they "continue to 
seek ways to improve" community relations (Gbemudu, 2010, para. 9). As could be seen from these statements, the company positioned itself such that stakeholders perceive it as being proactive in addressing the mistakes of the past. Proponents of the discourse of renewal suggested that organizations that engage in communicating learning are able to move beyond defensive communication, which focuses more on issues of blame.

Shell's communication also suggested elements of prospective vision as opposed to retrospective vision. Seeger et al. (2005) explained prospective vision as a situation in which organizational leaders focus their communication on a brighter future for both the organization and stakeholders, stressing the need for leaders and spokespersons to look beyond the crisis. In contrast, organizations enacting a retrospective vision during a crisis apply blame tactics and spend more time attributing responsibility for the causes of the crisis. Seeger et al. called on leaders and spokespersons to communicate in a manner that emphasizes a bright future, as this could spur optimism and willingness for stakeholders to collaborate with the organization to navigate the crisis. In many press statements, Shell officials portrayed the company as being proactive rather than defensive, focusing on the future. For example, the managing director and country chair of Shell in a 2014 news report promoted Shell's community development projects as indications of the "company's commitment to a long-term future for Nigeria" (Alike, 2014, para. 5). On another occasion, the director said, "Shell remains in the forefront of converting Nigeria's oil and gas resources to more jobs and opportunities for Nigerians" ("Shell Emerges Best Company," 2014, para. 5). This clearly takes the focus off a past crisis and encourages the people to anticipate a bright future with the company. Describing the performance of the company in the Niger Delta, the country director, speaking to communities at an award ceremony, explained that the development projects in Niger Delta communities "provided the best road map towards ensuring that the communities achieved socioeconomic empowerment and improved standard of living" (Oduma, 2011, para. 9). In another instance, the director told communities that the company's projects are "on course to significantly increasing Nigeria's oil and gas production while at the same time, delivering great 
benefits to the host communities" ("Shell to Sell," 2011, para. 4). These statements effectively point to an enviable future for the communities. The managing director told communities, "We remain committed to the sustainable development of the Niger Delta" (Oyadongha, 2011, para. 9). By continually evoking the terms "sustainable development" and "sustainability," Shell's communication clearly tied the company to a prospective vision.

Proponents of the discourse of renewal call on organizational leaders to effectively structure their crisis rhetoric such that organizational publics or stakeholders can make informed decisions. The emphasis is for leaders and spokespersons to frame the bigger picture in a crisis rather than focusing on the immediate causes of the crisis. But in doing so, leaders and spokespersons are advised to "frame the crisis in a way that inspires, empowers and motivates" (Sellnow \& Seeger, 2013, p. 98). In almost every instance wherein company officials communicated with communities, there were visible attempts to structure or construct public perception on the crisis and ensuing events. For example, addressing some communities in the Niger Delta during the launching of electricity-generating power plants, Shell's general manager for sustainable development and community relations told the people, "We recognize that electricity is key to socio-economic development, and that is why we have implemented these projects in addition to our interventions in economic empowerment, health, agriculture and human capital development" ("Shell Undertakes Electricity Projects," 2010, para. 3). In this statement, local communities are made to perceive a "bigger" picture of Shell by looking beyond electricity, which was actually the issue in question. At another address to communities, the managing director stated that the company has "a history of investing in social projects and programs in many communities in the [Niger Delta] region" (Onukwugha, 2011, para. 2). This statement implies a "history" of commitment to the welfare of communities. Another Shell official addressing local communities said, "We will continue to invest in the wellbeing of our people as we do business in the Niger Delta, and ask other stakeholders including communities themselves to be part of this noble effort" (Alike, 2011, para. 16). Officials promoted this theme of caring for communities by using catchphrases such as 
"powering progress together" (Alike, 2011, para. 3). This indeed is effective rhetoric framed such that organizational publics are "inspired" and "motivated" (Sellnow \& Seeger, 2013, p. 98). Similarly, Shell Nigeria's managing director told communities that the company "shall remain in the forefront of converting Nigeria's oil and gas resources to more jobs and opportunities for Nigerians" ("Shell Emerges Best Company," 2014, para. 5). At another occasion, the country director of Shell explained that a gas and oil project that was under construction was "good news for Nigeria" ("Shell First Oil Produced," 2014, para. 1), adding that being "a new source of oil revenue," the project "strengthens Nigeria’s deep-water expertise" ("Shell First Oil Produced," 2014, para. 1), which the director said is a "key driver of economic development" ("Shell First Oil Produced," 2014, para. 1). These are some instances of effective organizational rhetoric that not only attempted to structure reality but did so in a manner that motivated stakeholders true to the spirit of the discourse of renewal.

Summarily, Shell's discourse of renewal portrayed the multinational as being more transparent, accountable, responsible, honest, and trustworthy in its relationship with local stakeholders. The multinational also sought to show that the company was now engaging local communities in the management processes especially through the GMoUs, by emphasizing the need for teamwork and suggesting that communities could now "decide" and "drive" development projects. The company also portrayed itself as aligning with values of "sustainability," that is, achieving sustainable development in those communities. Also significant was the perception the company sought to construct among communities by portraying itself as a company working to prevent conflicts within and among local communities, continually stressing the need for peace among communities. By portraying the company as having learned from its past crisis management approach and actually showing how it was implementing lessons learned, Shell was repositioning itself as a benefactor of the renewal of the Delta region and its resources.

\section{Outcomes of Shell's Discourse of Renewal}

Despite evidence that Shell adopted a discourse of renewal in recent years, conflicts, disruptions, and general opposition to the company's 
presence in the Niger Delta have continued. The primary point of contestation remains land and oil ownership claims, and these claims remain unaddressed in the company's discourse of renewal.

First, while Shell executives advanced a prospective rhetoric of regional renewal, people in affected communities remained disaffected and unwilling to abandon ancestral lands and communal claims. During one riot against Shell, 3 people died and 100 were injured. The leader of one of the protesting communities asserted,

It is a known fact that Uzere kingdom has been blessed with oil and gas in its land. It is also a known fact that Shell took the advantage to exploit these natural resources on our fatherland for the past 52 years. (Amaize, 2011, para. 9)

In another instance, community protesters in another community charged that "Shell is taking our oil," and they seemed to reject the company's vision of a shared prosperity for a narrative of Shell as exploiting gas reserves: "We were told that gas Shell is taking from our land is the largest, our community being the largest natural gas reserve in West Africa" (Yafugborhi, 2012, para. 4). These persistent claims over land construct a counterreality in which Shell's land leases and petroleum-sharing contracts signed with the Nigerian government cannot legitimize its operations in this region nor frame the vision of cooperative stakeholder relations that the company espouses.

Similarly, despite a rhetorical emphasis on transparency, accountability, and trustworthiness, local communities perceived a failure of the company to negotiate with the people and a lack of respect for their authority. As one villager observed, "the company did not enter into any agreement with the people" and failed "to come to [our village] to discuss" (Amaize, 2011, para. 12). Given the traditional structure of communal decision-making in the contemporary Niger Delta (see Amodu, 2013), these perceptions constructed a counterreality about Shell's outreach efforts in the Delta region. Negotiation was also evoked as protesting communities justified their protests, asserting that

"the protest and the shutdown of the two flow stations were due to the failure of the [company] to respect the host communities" noting that 
"to our greatest displeasure and dismay, we were made to understand through the media" that an oil well "has been sold out, yet we are not in the picture." (James, 2015, para. 7)

The failure of negotiation is also related to another point of contention-community representatives. Protesting communities continue to contest who should negotiate on behalf of communities and to insist that Shell's companies in the Niger Delta "commence negotiation, with the proper authorized agents of the communities" (Dugbe, 2014, para. 2). Shell was accused of inviting "unauthorized members of affected communities" (Uwugiaren, 2016, para. 6) into negotiations. In one newspaper report, protesters accused Shell of inviting "chairmen of 24 communities to sign nefarious agreements on behalf of the impacted communities" (Uwugiaren, 2016, para. 8), adding that the affected communities "will definitely file a separate claim against Shell in any court of law should Shell fail to commence negotiation with our said representative/attorney" (Uwugiaren, 2016, para. 18). The complexities of land and authority thus complicate a discourse of renewal in the Nigerian context.

Third, the company was perceived as not implementing the lessons its leaders and spokespersons claimed the company had learned. Shell's discourse of renewal was belied by ongoing oil spills and gas flaring, unemployment, and inadequate basic services. A Taylor Creek community leader who led a protest of 200 women said, "Shell is taking our oil and has continued to deny the community potable water, health center, light; employment of our youths and adequate intra community roads" (Yafugborhi, 2012, para. 5; cf. James, 2015; Senior, 2011; "We've Not Violated GMoU," 2011). Perceptions of the company's leadership were also undermined by widespread public perceptions of corruption in the company.

Fourth, while the GMoU agreement is depicted as contributing to community autonomy and creating a participatory relationship with the people themselves-evidence of renewal-these relationships nonetheless reproduce neocolonialist relations in that they create artificial empowerment and patronizing benevolence, like a benefactor giving money to a dependent rather than respecting the authority and 
autonomy of the community itself. Therefore the renewal Shell is touting has to do with "renewing" a neocolonialist relationship in which an external agent "colonizes" the resources of the Delta communities. Despite all the ethical promises, this relationship remains at the heart of the company's presence in Africa.

\section{Lessons Learned}

The case of Royal Dutch Shell in Nigeria inspires reflections on applying crisis communication models in multinational and African contexts:

1. Expand the parameters of "crisis" beyond the interests and reputation of the corporation to give adequate attention to situational exigencies in a crisis communication plan. In the case of Royal Dutch Shell in Nigeria, the complex nature of claims over land and oil ownership are identified as compelling examples of how histories and situational exigencies contextualize crisis communication practices.

2. Revisit the conception of leadership to move beyond a Westerncentric focus on corporate executives and spokespersons. At the same time, the emphasis on leadership encourages an unreflective focus on titular leaders as community representatives and may deflect attention from more communal and distributed modes of decision-making. The way communities in the Niger Delta are organized shows clearly that there are communal modes of organizing, which suggests that authority is more broadly distributed, that leadership cannot be read off social positions, and that leaders cannot adopt a model of communication as the transmission of a preferred vision of reality to passive stakeholders (even if it is prospective).

3. Reframe a prospective stance to acknowledge ancestral presence and cultural traditions as integral to an orientation that is present oriented.

4. Consider a more radical conception of renewal that addresses the dangers of corporate benevolence and neocolonialism. In the case of Shell, the GMoU may empower village groups to 
determine development projects, yet these groups, their authority, and their projects depend on Shell's funding, support, and resources. Renewing relations with villages in the Delta region that move beyond corporate largess may entail redefining renewal.

\section{Conclusion}

The Nigerian case offers an example of crises that cannot be addressed only by responding to the accusations of wrongdoing and immediate causes of the crisis. Beneath these accusations are contextual tensions, situational exigencies that could better be understood and addressed by paying critical attention to the histories and the cultural, social, and economic relations within which these allegations of wrongdoing and tensions emerge. The precolonial, colonial, and postcolonial experiences within which Nigeria emerged hugely contribute to the complexities of the crisis in the Niger Delta region. The conflicting claims over land and crude oil, for example, are the result of conflicting land use acts enacted during the colonial and then postcolonial administrations. Despite Shell's enactment of a discourse of renewal through GMoUs that restructure relationships with local communities, an emphasis on values and ethical leadership, and a prospective vision, protests and local resistance persist. In the parlance of popular management prescriptions, multinationals must not only talk about renewal but have also to "walk the talk." While it is beyond the scope of this article to expand on this injunction, at a minimum, this entails a grounded understanding of everyday life in local settings so that "renewal" is appropriate and responsive to lived cultural, social, and material conditions. Regardless of how well Shell's communication strategies realize tenets of renewal, the difficult work of changing established and legally justified practices and distributions is where a redefined renewal becomes actionable. The lessons learned in this case offer a first step toward amending the model of renewal to account for non-Western exigencies and legacies. 
Vincent D. Manzie, $\mathrm{PhD}$, is a visiting assistant professor of applied communication studies at the University of Arkansas, Little Rock. His research and teaching draw from a critical/cultural communication orientation to bear on issues of inclusion, equity, and social justice in "real-world" situations.

\section{ORCID}

Vincient D. Manzie (1) https://orcid.org/oooo-0oo3-3759-4933

\section{Note}

1. For a discussion on land regulations in Nigeria, see Udoekanem, Adoga, and Onwumere (2014).

\section{References}

Alagoa, E. J. (2004). The uses of hindsight as foresight: Reflections on Niger Delta and Nigerian history. Port Harcourt, Nigeria: Onyoma Research Publications.

Alike, E. (2011, July 5). Shell seeks dialogue as Bayelsa Youths protest. This Day. Retrieved from LexisNexis Academic database.

Alike, E. (2014, November 5). Shell executes N2 billion projects to mark Nigerias centenary. This Day. Retrieved from LexisNexis Academic database.

Alike, E. (2015, December 16). Again, Shell faces Dutch court over Niger Delta oil damage. Retrieved from LexisNexis Academic database.

Amaize, E. (2011, December 10). How three people died, 100 injured as community clashes with security agents. Vanguard. Retrieved from LexisNexis Academic database.

Amanze, C. (2012, July 5). 30 oil wells-FG plans new peace talks with Ogonis. This Day. Retrieved from LexisNexis Academic database.

Amodu, L. O. (2013). Community relations strategies and conflict resolution in the Niger Delta: A study of three major oil companies. Retrieved from http:// covenantuniversity.edu.ng/Profiles/Amodu-lanre/community-relations 
-strategies-and-conflict-resolution-in-the-niger-delta-a-study-of-three -major-oil-companies

Benoit, W. L. (1997). Image repair discourse and crisis communication. Public Relations Review, 23, 177-186. https://doi.org/10.1016/So363-8111(97)90023-o Chinwo, E. (2013, September 25). Shell GMoU earns community N50 million multi-purpose hall, others. This Day. Retrieved from LexisNexis Academic database.

Cook, T. (2012, May 28). Nigeria oil bill to outlaw gas flaring by end-2012. Retrieved from https://af.reuters.com/article/investingNews/idAFJO E84RoA820120528

Coombs, W. T. (2007). Protecting organization reputations during a crisis: The development and application of situational crisis communication theory. Corporate Reputation Review, 10, 163-176. https://doi.org/10.1057 /palgrave.crr.1550049

Dugbe, J. (2014, November 25). Shoreline communities give SPDC seven-day ultimatum over oil spillage. Daily Independent. Retrieved from LexisNexis Academic database.

Gbemudu, E. (2010, December 21). Bayelsa lauds SPDC on GMoU implementation. Daily Independent. Retrieved from LexisNexis Academic database.

George, L., \& Owolabi, T. (2018, February 14). Appeal court rules Nigerians cannot pursue Shell spill claim in England. Retrieved from https://www .reuters.com/article/us-shell-nigeria-court/appeal-court-rules-nigerians -cannot-pursue-shell-spill-claim-in-england-idUSKCN1FY1Vo

Iwori, J. (2014, November 26). Host community opposes sale of OML 29. This Day. Retrieved from LexisNexis Academic database.

James, S. (2015, May 23). Youths shut down oil production in Nembe Creek. This Day. Retrieved from LexisNexis Academic database.

Mark, M. (2012, May 31). Nigeria's penalty for gas flaring will not curb emissions, say campaigners. The Guardian. Retrieved from https://www .theguardian.com/environment/2012/may/31/nigeria-penalty-gas-flaring McGreal, C. (1993, August 11). Spilt oil brews up a political storm; Chris McGreal reports from the Niger Delta on the Ogoni people response to Shell's pollution record. The Guardian. Retrieved from LexisNexis Academic database.

Niger Delta Development Commission. (2005). Niger Delta regional development master plan. Retrieved from http://www.nddc.gov.ng/masterplan.html Nwachuku, C. (2015, May 6). Social investment, key to sustainable develop- 
ment-Shell. Vanguard. Retrieved from LexisNexis Academic database. Nzeshi, O. (2013, February 6). House tasks UNEP on oil pollution in Ogoniland. This Day. Retrieved from LexisNexis Academic database.

Oduma, I. (2011, June 22). SPDC splashes N103 million on self-reliance programme. Daily Independent. Retrieved from LexisNexis Academic database.

Ogbu, A. (2012, March 2). Jonathan charges Shell on oil spills. This Day. LexisNexis Academic.

Onah, G. (2010, November 4). Shell awards scholarships to 50 rivers students. Retrieved from LexisNexis Academic database.

Onukwugha, A. (2011, August 23). Shell to sustain GMoU with Niger Delta communities. Leadership. Retrieved from LexisNexis Academic database.

Oyadongha, S. (2011, March 3). Bayelsa communities, SPDC implement GMoU, award 130 students scholarship. Vanguard. Retrieved from LexisNexis Academic database.

Reierson, J., \& Littlefield, R. S. (2012). History, healing, and hope: Reconceptualizing crisis renewal theory by developing a model for marginalized communities. Review of European Studies, 4(4), 29-44. https://doi .org/10.5539/res.v4n4p29

Seeger, M. W., \& Ulmer, R. R. (2001). Virtuous responses to organizational crisis: Aaron Feuerstein and Milt Cole. Journal of Business Ethics, 31, 369-376. https://doi.org/10.1023/A:1010759319845

Seeger, M. W., \& Ulmer, R. R. (2002). A post-crisis discourse of renewal: The cases of Malden Mills and Cole Hardwoods. Journal of Applied Communication Research, 30, 126-142. https://doi.org/10.1080/0090988 0216578

Seeger, M. W., Ulmer, R. R., Novak, J. M., \& Sellnow, T. L. (2005). Postcrisis discourse and organizational change, failure and renewal, Journal of Organizational Change Management, 18(1), 78-95. https://doi .org/10.1108/09534810510579869

Sellnow, T. L., \& Seeger, M. W. (2013). Theorizing crisis communication. Malden, MA: Wiley-Blackwell.

Shell oil spill data. (n.d.). Retrieved from https://www.shell.com.ng/sustain ability/environment/oil-spills.html

Shell emerges best company in stakeholder engagement, human rights. (2014, November 10). Daily Independent. Retrieved from LexisNexis Academic database. 
Shell first oil produced from SNEPCO-operated Bonga North West Deepwater Project in Nigeria. (2014, August 6). Global Data. Retrieved from LexisNexis Academic database.

Shell Nigeria. (2012, April). Global memorandum of understanding. Retrieved from http://www.shell.com.ng/sustainability/communities/gmou.html Shell to sell about $\$ 1$ billion of assets in Africa. (2011, February 20). Daily Independent. Retrieved from LexisNexis Academic database.

Shell undertakes electricity projects in 133 communities. (2010, May 13). Vanguard. Retrieved from LexisNexis Academic database.

Steele, J. (1995, November 11). Bloody deeds raised against a people's struggle to control their resources, suppression of protest at the rape of the Niger Delta has been sordid and violent. The Guardian. Retrieved from LexisNexis Academic database.

Udoekanem, N. B., Adoga, D. O., \& Onwumere, V. O. (2014). Land ownership in Nigeria: Historical development, current issues and future expectations. Journal of Environment and Earth Science, 4, 182-188.

Ulmer, R. R. (2001). Effective crisis through stakeholder relationships: Malden Mills as a case study. Management Communication Quarterly, 14, 590-615. https://doi.org/10.1177/08933189011144003

Ulmer, R. R., \& Sellnow, T. L. (2002). Crisis management and the discourse of renewal: Understanding the potential for positive outcomes of crisis. Public Relations Review, 28, 361-365. https://doi.org/10.1016/So363-8111(02)00165-o Ulmer, R. R., Sellnow, T. L., \& Seeger, M. W. (2007). Effective crisis communication: Moving from crisis to opportunity. Thousand Oaks, CA: Sage. Ulmer, R. R., Seeger, M. W., \& Sellnow, T. L. (2007). Post-crisis communication and renewal: Expanding the parameters of post-crisis discourse. Public Relations Review, 33, 130-134. https://doi.org/101016/j.pubrev.2006 .11 .015

Ulmer, R. R., Sellnow, T. L., \& Seeger, M. W. (2011). Effective crisis communication: Moving from crisis to opportunity (2nd ed.). Thousand Oaks, CA: Sage. Uwugiaren, I. (2016, July 11). Bonga oil spill, Niger Delta communities raise the alarm over Shell's crude tactics. This Day. Retrieved from LexisNexis Academic database.

Ware, B. L., \& Linkugel, W. A. (1973). The spoke in defense of themselves: On the generic criticism of apologia. Quarterly Journal of Speech, 3, 273-283. Retrieved from https://doi.org/10.1080/00335637309383176 
We've not violated GMoU on EA oil field-Shell. (2011, February 8). Vanguard. Retrieved from LexisNexis Academic database.

Yafugborhi, E. (2012, July 24). Koroama women protest alleged neglect by Shell. Vanguard. Retrieved from LexisNexis Academic database.

Yin, R. K. (2009). Case study research: Design and methods (4th ed.). Thousand Oaks, CA: Sage. 